\title{
PENERAPAN KONSEP COMMUNITY BASED TOURISM (CBT) DI DESA WISATA CANDIREJO BOROBUDUR MEWUJUDKAN KEMANDIRIAN DESA
}

\author{
Retno Dewi Pramodia Ahsani ${ }^{1}$, Oktavia Suyaningsih ${ }^{2}$, Nur Ma'rifah ${ }^{3}$, Elsa Aerani ${ }^{4}$ \\ 1,2,3,4 Program Studi Ilmu Administrasi Negara, Fakultas Ilmu Sosial dan Ilmu Politik \\ Universitas Tidar, Magelang \\ Email: ${ }^{1}$ pramodiaahsani@gmail.com
}

\begin{abstract}
This study aims to examine about the impact of application of the concept of Community Based Tourism (CBT) in realizing the independence of Candirejo village. The research method used is qualitative method. The results of this study are Candirejo Village Management Manager is a Cooperative whose entrepreneurs are the original community of Candirejo Village, The impact of CBT concept implementation can be seen through economic aspects (job diversification, improvement of housing condition and new business development), social (social interaction, community participation, change of mindset), cultural adoption, and environment (improvement of public facilities). With the fulfillment of Indicator Independence of the village is not entirely Candirejo village can be released of the government aid funds, but at least in the fulfillment of basic needs, community activities, construction of public facilities, and economic activities available can be fulfilled independently.
\end{abstract}

Keyword: Tourism Village, Community Based Tourism, Independent.

\section{PENDAHULUAN}

Indonesia merupakan salah satu negara yang terkenal melalui sektor pariwisata. Keindahan alam Indonesia yang terbentang dari sabang sampai merauke dengan beragam kebudayaan, adat istiadat, agama, maupun bahasanya mampu menarik hati wisatawan baik lokal dan mancanegara. Berbagai wilayah baik kota maupun pedesaan kini mulai berlomba melakukan perubahan, konsep yang berkembang merupakan paradigma pertumbuhan (growth paradigm), pemikiran yang memperjuangkan terjadinya peningkatan pendapatan masyarakat dan pendapatan negara. (Sulistiyani, 2004) kondisi tersebut ibarat dayung bersambut segala sector mulai dikembangkan salah satunya adalah munculnya berbagai macam konsep desa wisata.

Volume 3, Nomor 2, Oktober 2018
Desa wisata merupakan merupakan suatu bentuk integrasi antara atraksi, akomodasi, dan fasilitas pendukung yang disajikan dalam suatu struktur kehidupan masyarakat yang menyatu dengan tata cara dan tradisi yang berlaku. suatu wilayah pedesaan dengan keseluruhan suasana yang mencerminkan keaslian desa, baik dari struktur ruang, arsitektur bangunan, pola kehidupan sosial budaya masyarakat, serta mampu menyediakan komponen-komponen kebutuhan pokok wisatawan seperti akomodasi, makanan dan minuman, cinderamata dan atraksi-atraksi wisata (Nuryanti, 1992). Konsep desa wisata lebih pada konsep pengembangan dan pemberdayaan masyarakat yang berangkat dari potensi yang dimiliki pada tataran wilayah tertentu sehingga perwujudan pelayanannya dengan menyuguhkan PUBLISIA: Jurnal Ilmu Administrasi Publik | 135 
keindahan alam, budaya maupun adat istiadat yang ada didesa tersebut.

Penerapan Desa Wisata telah banyak diterapkan dibeberapa daerah di Indonesia, salah satunya di Desa Candirejo Kabupaten Magelang Jawa Tengah, berjarak $3 \mathrm{~km}$ dari Candi Borobudur berbatasan dengan Desa Kesongo, Desa Pulutan, Jombor dan Rawapening. Desa wisata Candirejo menawarkan keindahan alam yang indah dan aktifitas yang menunjukkan kearifan lokal masyarakat setempat. Wisatawan yang berkunjung akan ditawarkan sejumlah paket wisata yang terdapat di desa Candirejo diantaranya Tamasya keliling desa, wisata, sistem pertanian desa, Pendidikan lingkungan, kehidupan masyarakat setempat (home stay), dan kesenian tradisional.

Paket wisata yang ditawarkan di desa wisata Candirejo dapat dikategorikan menerapkan konsep Community Based Tourism (CBT) sebuah konsep yang lahir berdasarkan pemikiran Bank Dunia dalam rangka penanggulangan kemiskinan melalui sektor pariwisata pada tahun 2000. CBT merupakan sebuah kegiatan pembangunan pariwisata yang dilakukan sepenuhnya oleh masyarakat. Ide kegiatan dan pengelolaan dilakukan seluruhnya oleh masyarakat secara partisipatif, dan manfaatnya dirasakan langsung oleh masyarakat lokal (Dewi, 2013). Pada konsep CBT ini ada tiga kegiatan besar yang dilakukan yaitu: adventure travel, cultural travel, ecotourism. Di desa wisata Candirejo adventure travel ( tamasya keliling desa), cultural travel (wisata menoreh, kesenian tradisional), dan ecotourism (Sistem Pertanian Desa, Pendidikan lingkungan). Dengan menerapkan konsep CBT, koperasi Desa Wisata Candirejo telah mampu mengelola keuangan dengan jumlah cukup besar bagi yaitu Rp. 1.016.297.325,- (LPJ Koperasi Desa Wisata Candirejo,2016)

Jumlah pengunjung desa wisata Candirejo dari tahun ke tahun mengalami peningkatan baik dari domestik maupun mancanegara, seperti tergambar pada grafik berikut;

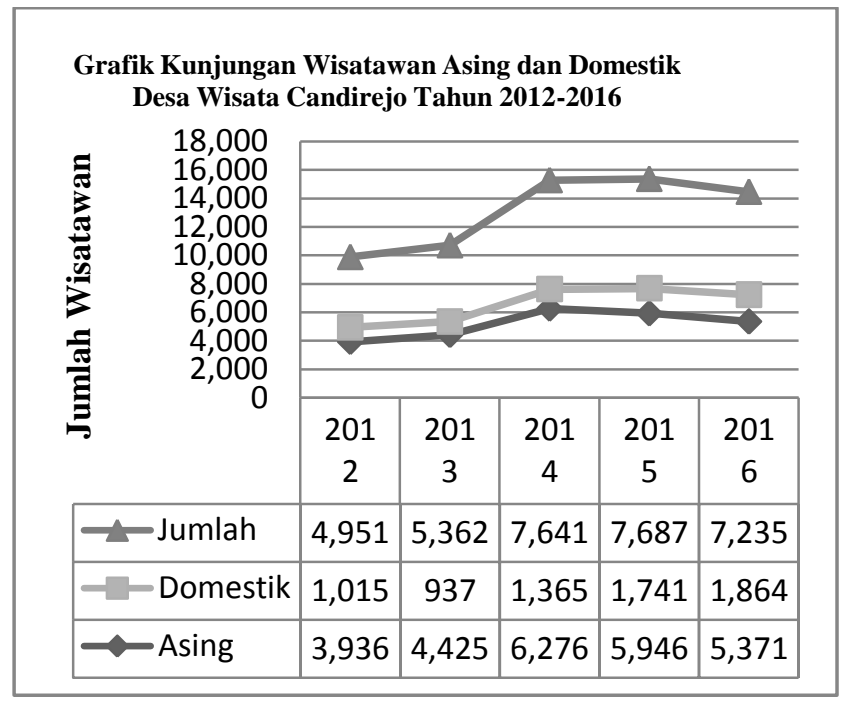

Sumber: RAT Candirejo, 2016

Grafik diatas menunjukkan bahwa jumlah pengunjung desa wisata meningkat dari tahun ke tahun sejak tahun 2012-2015, kemudian pada tahun 2016 mengalami sedikit penurunan jumlah pengunjung, kondisi tersebut memberikan kontribusi besar terhadap kesejahteraan anggota Koperasi Desa wisata Candirejo melalui pendapatan kas koperasi. Kesejahteraan yang dinikmati oleh anggota Komunitas, apakah juga berdampak kepada masyarakat desa Candirejo secara umum. Dengan kondisi yang ada maka penelitian ini ingin mengkaji lebih dalam tentang dampak penerapan konsep CBT dalam mewujudkan kemandirian desa Candirejo. 
METODE

Metode kualitatif dijadikan sebagai instrument dalam mengkaji lebih dalam atas objek yang diteliti dan bersifat induktif.

\section{KAJIAN TEORI}

\section{Implementasi Kebijakan}

Meter dan Horn (1975) mendefenisikan implementasi kebijakan sebagai tindakan yang dilakukan oleh pemerintah maupun swasta baik secara individu maupun kelompok yang dimaksudkan untuk mencapai tujuan sebagaimana dirumuskan di dalam kebijakan. Dalam mengukur kinerja suatu kebijakan dapat merujuk pada Purwanto dan Sulistyastuti (2012) yang mendefinisikan sebagai gambaran mengenai tingkat pencapaian implementasi dalam mewujudkan sasaran dan tujuan suatu kebijakan, baik itu berupa keluaran kebijakan (policy output), maupun hasil kebijakan (policy outcome)suatu kebijakan sendiri, yang dapat diartikan bahwa kinerja dapat diartikan sebagai keberhasilan. Dalam pengukuran kinerja implementasi suatu kebijakan, indikator dalam mengukur kinerja dibedakan menjadi dua, yaitu indikator output dan indikator outcome (Purwanto dan Sulistyastuti, 2012).

Indikator output digunakan untuk mengetahui konsekuensi langsung yang dirasakan oleh kelompok sasaran sebagai akibat adanya realisasi kegiatan, aktivitas, pendistribusian hibah, subsidi, dan lain-lain yang dilaksanakan dalam implementasi suatu kebijakan.(ibid) Adapun indikator kedua yaitu indikator outcome, indikator ini lebih mengukur kinerja berdasarkan dampak yang dirasakan oleh kelompok sasaran. Manfaat lain dari mengetahui dampak kebijakan adalah: 1). Untuk menguji implementasi suatu pilot project apakah dapat dikembangkan menjadi suatu program; 2). Untuk mengetahui design suatu program yang paling efektif sehingga ditemukan suatu cara untuk mengintegritaskan berbagai program; 3). Untuk menguji apakah modifikasi suatu program membuahkan hasil atau tidak; dan 4). Untuk mengambil keputusan terhadap keberlangsungan suatu program.

\section{Konsep Community Based Tourism (CBT)}

Menurut Suansri (2003) Community Based Tourism (CBT) merupakan pariwisata yang memperhitungkan aspek keberlanjutan lingkungan, sosial, dan budaya. Konsep ini merupakan paradigma baru dalam pengelolaan pariwisata. Suansri (2003) mengemukakan beberapa prinsip yang harus dipegang teguh dalam pelaksanaan Community Based Tourism. Prinsip tersebut antara lain:

1. Mengakui dan mendukung serta mengembangkan kepemilikan komunitas dalam industri pariwisata;

2. Mengikutsertakan anggota komunitas dalam memulai setiap aspek;

3. Mengembangkan kebanggaan komunitas;

4. Mengembangkan kualitas hidup komunitas;

5. Menjamin keberlanjutan lingkungan;

6. Mempertahankan keunikan karakter dan budaya di area local;

7. Membantu berkembangnya pembelajaran tentang pertukaran budaya pada komunitas;

8. Menghargai perbedaan budaya dan martabat manusia;

9. Mendistribusikan keuntungan secara adil pada komunitas; dan 
10. Berperan dalam menentukan prosentase pendapatan.

\section{Partisipasi Masyarakat dan Kemandirian Desa}

Masyarakat lokal dapat berpartisipasi dalam pengembangan desa wisata mulai dari awal perencanaan, implementasi, monitoring, dan evaluasi. Adiyoso (2009) menegaskan bahwa partisipasi masyarakat merupakan komponen terpenting dalam upaya pertumbuhan kemandirian dan proses pemberdayaan. Pengabaian partisipasi masyarakat lokal dalam pengembangan desa wisata menjadi awal dari kegagalan tujuan pengembangan desa wisata (Nasikun, 1997). Kemudian menurut Cohen dan Uphoff (1979) peran atau partisipasi yang dilakukan oleh masyarakat bisa dilihat mulai dari tahap perencanaan, pelaksanaan, pengelolaan atau pemanfaatan, pengawasan, menikmati hasil dan evaluasi.

Memberdayakan masyarakat sama artinya dengan memampukan dan memandirikan masyarakat. Widjaja (2011) telah menjelaskan bahwa inti dari pemberdayaan adalah upaya membangkitkan segala kemampuan desa yang ada untuk mencapai tujuan. Pencapaian tujuan dilakukan melalui penumbuhan motivasi, inisiatif, dan kreativitas untuk memajukan perekonomian dan membawa kesejahteraan bagi desa. Kemudian, upaya pemberdayaan warga desa ini diwujudkan melalui BUMDes yang telah berhasil dibentuk di dalamnya. Dengan berkembangnya desa wisata, tujuan dan harapannya adalah desa mampu menjadi mandiri dan dapat meningkatkan derajat ekonomi warga sekitar.

\section{Badan Usaha Milik Desa (BUMDes)}

Salah satu instrumen penting dalam mewujudkan desa mandiri adalah membentuk BUMDes. BUMDes dapat dijadikan sebagai wadah warga setempat dalam melakukan pemberdayaan dan kemandirian desa dari destinasi desa wisata yang telah ditawarkan. Sebab desa dipandang sebagai sebuah kesatuan masyarakat hukum atau badan hukum publik juga memiliki kewenangan meskipun tidak seluas kewenangan yang dimiliki oleh pemerintah daerah. Kewenangan desa adalah hak desa untuk mengatur, mengurus, dan bertanggung jawab atas urusan pemerintah dan kepentingan masyarakat setempat; apa yang dimaksud dengan "mengatur" dan "mengurus" serta apa yang dimaksud dengan "urusan pemerintahan" dan "kepentingan masyarakat setempat".

Menurut UU No 6 Tahun 2014 tentang Desa, BUMDes adalah badan usaha yang secara keseluruhan atau sebagian besar modalnya dimiliki oleh desa melalui penyertaan secara langsung yang berasal dari kekayaan desa yang dipisahkan guna mengelola aset, jasa pelayanan, dan usaha lainnya, sebesar-besarnya untuk kesejahteraan masya- rakat desa. Dalam implementasinya, pemerintah kabupaten/kota menetapkan peraturan daerah (Perda) tentang pedoman tata cara pembentukkan dan pengelolaan BUMDes. Ketentuan ini bersifat mandatory, bukan voluntary sehingga pengelolaan BUMDes sesuai dengan karakteristik wilayah masing-masing (Permendagri No 38/2010 tentang BUMDes).

Beberapa indikator kemandirian desamenurut Agusta dan Fujiartanto(2004: 66- 
67) sebagai berikut: 1). Kebutuhan Dasar; 2). Kegiatan Kemasyarakatan; 3). Fasilitas Publik; dan 4). Kegiatan Ekonomi.

\section{HASIL DAN PEMBAHASAN}

Desa Candirejo terletak $3 \mathrm{~km}$ kearah tenggara dari pusat peradaban dunia Candi Borobudur. Awal mula perintisan konsep desa wisata Candirejo pada tahun 1997 dengan membentuk kelompok kerja dari tinngkat dusun hingga tingkat desa yang dilakukan oleh masyarakat dan perangkat desa, sehingga model pembangunan ini lebih mewujudkan pola bottom-up, walau pada pelaksanaannya seperti dayung bersambut kelompok Pemerintah dan Perangkat Desa memberikan inovasi dan evaluasi dalam setiap pelaksanaan. Pemerintah Kabupaten Magelang memberikan respon positif dengan menjadikan Desa Candirejo sebagai salah satu pilot project Desa Wisata di Kabupaten Magelang pada tanggal 31 Mei 1999 melalui SK Bupati Magelang No.556/1258/19/1999. Desa Candirejo kemudian ditetapkan menjadi Desa Binaan Wisata Tk.Kab Magelang pada tahun 1999-2003. Kegiatan-kegiatan yang dilaksanakan sejak tahun 1999-2003 di desa Candirejo lebih mengarah pada pembinaan dan penguatan pelaku wisata, kemudian pada 19 april 2003 mulailah Desa Candirejo diresmikan menjadi Desa Wisata oleh I Gede Ardika (Menteri Pariwisata dan Kebudayaan Republik Indonesia). Pada tahun yang sama dibentuklah pengelola Pariwisata Desa Candirejo dalam satu kelompok kerja yaitu Koperasi Desa Wisata Candirejo yang tertuang dalam SK Desa No.04/KEPDES/05/2003.

Pengelolaan Desa Wisata Candirejodan Dampak penerapan konsep Community Based Tourism (CBT)

Desa Wisata Candirejo yang menyajikan berbagai macam jenis wisata dikelola oleh koperasi desa wisata Candirejo yang diketuai oleh Tatak Sariawan. System kerja Koperasi berbeda dengan penyelenggaraan pemerintahan desa namun bertanggung jawab untuk menyerahkan laporan pelaksanaan kepada pemerintah desa Candirejo. Koperasi ini terdiri dari sejumlah komunitas seperti komunitas kusir andong, pemilik homestay, pengelola wisata alam watu kendil, home industry, local guide, pertanian, kesenian, sepeda onthel, rafting dan lain-lain yang merupakan masyarakat asli desa wisata Candirejo, seperti yang tergambar pada diagram berikut; 


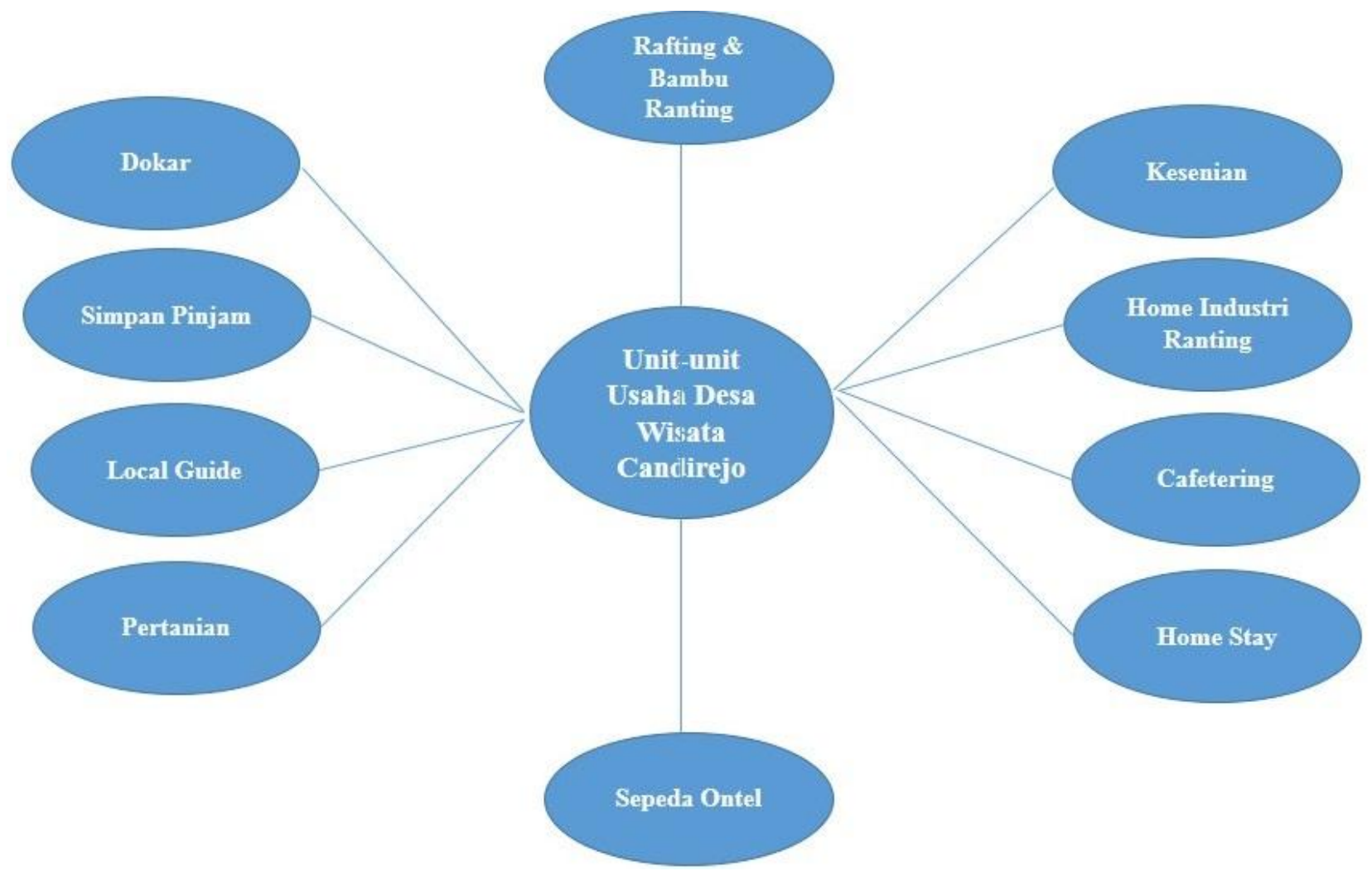

Sumber: dokumentasi peneliti, 2017.

Pengelolaan desa wisata dilakukan sepenuhnya oleh masyarakat desa dengan mengembangkan potensi desa yang dimiliki tanpa harus meninggalkan kegiatan seharihari dan kearifan local yang ada, sehingga masyarakat secara tidak langsung terus melakukan inovasi sehingga memberikan nilai tambah dan memberikan manfaat baik secara ekonomi maupun non-ekonomi terhadap komunitasnya. konsep CBT ini dilaksanakan di desa Wisata Candirejo memiliki tujuan luhur yaitu dapat meningkatkan kesejahteraan masyarakat secara keseluruhan karena melalui pengembangan tidak hanya pada tataran Sumber Daya Alam (SDA) saja yang diberdayakan tetapi juga masyarakat ikut terlibat langsung dalam setiap penyelenggaraan kegiatan wisata sebab tanpa disadari sebenarnya potensi terbesar dari suatu desa adalah Sumber Daya Manusia (SDM), apabila mereka yang bekerja di sector informal digerakkan untuk bekerja mengembangkan prduk yang diunggulkan di desa tentu sudah kondisi ini merupakan asset SDM yang luar biasa (Sumodiningrat, 2016).

Konsep penerapan CBT dengan lahirnya suatu Koperasi menjadi wadah masyarakat mengembangkan potensi, sehingga pada pelaksanaan desa wisata setiap aktivitas ekonomi yang ada memberikan kontribusi yang dikelola secara bersama, adapun pengurus koperasi Desa Wisata Candirejo dapat dilihat pada gambar di bawah; 


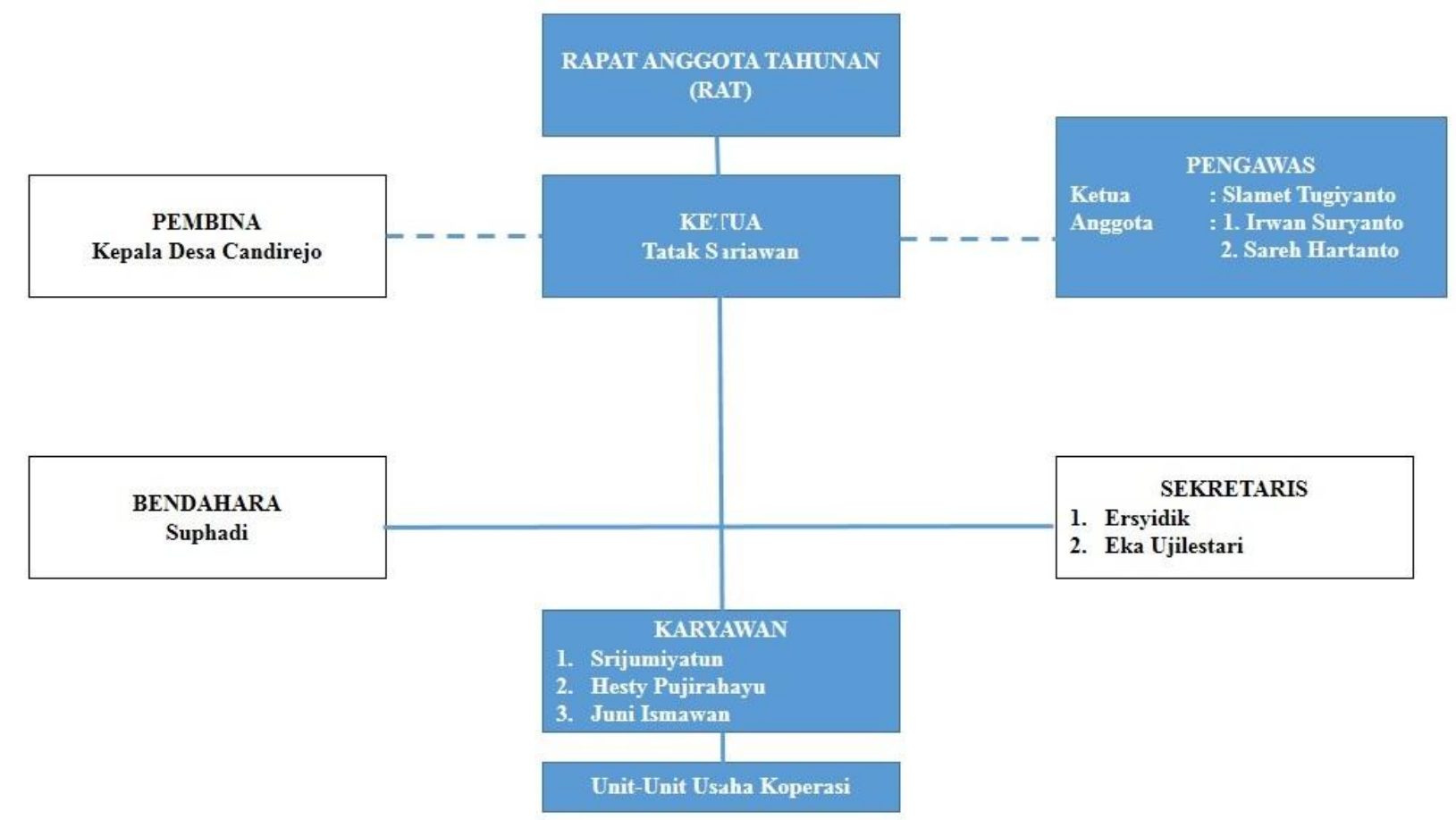

Dampak Penerapan Community Based Tourism (CBT) di desa wisata Candirejo.

\section{Dampak Ekonomi}

Penerapan konsep CBT di Desa Wisata Candirejo memberikan dampak ekonomi pada masyarakat diantaranyaadanya diversifikasi pekerjaan. Masyarakat lokal Desa Wisata Candirejo yang mayoritas merupakan petani kini memiliki pekerjaan lain selain sebagai seorang petani.

Berikut pekerjaan yang muncul setelah menjadi desa wisata.

\begin{tabular}{cll}
\hline N & \multicolumn{1}{c}{ Jenis Pekerjaan } & \multicolumn{1}{c}{ Jumlah } \\
o. & \multicolumn{1}{c}{ Baru } & \\
\hline 1 & Pengurus koperasi & 7 orang \\
2 & Pemandu wisata/ & 11 orang \\
& local guide & \\
3 & Pemilik Homestay & 12 orang \\
4 & Pelaku kesenian & 5 kelompok \\
5 & $\begin{array}{l}\text { Pelaku wisata } \\
\text { lainnya }\end{array}$ & 41 orang \\
\hline
\end{tabular}

Sumber: RAT Candirejo, 2016.
Diversifikasi pekerjaan yang terjadi berdampak pada peningkatan penghasilan masyarakat. Pendapatan diterima masyarakat dari pihak Koperasi Desa Wisata Candirejo yang berasal dari pembagian Sisa Hasil Usaha (SHU) pendapatan desa Wisata. Berikut Tabel Pendapatan dan Pembagian SHU Desa Wisata Candirejo Tahun 2012-2016.

\begin{tabular}{ccc}
\hline Tahun & $\begin{array}{c}\text { Jumlah } \\
\text { Pendapatan }\end{array}$ & $\begin{array}{c}\text { Sisa Hasil } \\
\text { Usaha }\end{array}$ \\
\hline 2012 & 398.219 .450 & 21.349 .735 \\
2013 & 505.801 .275 & 41.081 .187 \\
2014 & 651.479 .225 & 48.657 .186 \\
2015 & 1.016 .297 .325 & 74.000 .475 \\
2016 & 885.769 .775 & 125.345 .475 \\
\hline Sumber: RAT Candirejo, 2016. \\
\multicolumn{4}{c}{ Pembagian Sisa Hasil Usaha Koperasi } \\
Desa Wisata Candirejo Tahun 2016:
\end{tabular}




\begin{tabular}{|c|c|c|c|}
\hline No. & Keterangan & $\%$ & $\begin{array}{l}\text { Jumlah } \\
\text { (Rp) }\end{array}$ \\
\hline 1. & Anggota & 35 & 41.982 .351 \\
\hline 2. & $\begin{array}{l}\text { Pemupukan } \\
\text { Modal } \\
\text { Koperasi/ } \\
\text { BUMDes }\end{array}$ & 15 & 17.992 .436 \\
\hline 3. & $\begin{array}{l}\text { Aset } \\
\text { Kepemilikan } \\
\text { Lahan }\end{array}$ & 15 & 17.992 .436 \\
\hline 4. & $\begin{array}{l}\text { Pengurus, BP, } \\
\text { Karyawan }\end{array}$ & 15 & 17.992 .436 \\
\hline 5. & $\begin{array}{l}\text { Pendapat Asli } \\
\text { Desa }\end{array}$ & 12 & 14.393 .949 \\
\hline 6. & $\begin{array}{l}\text { Dana } \\
\text { Pendidikan, } \\
\text { Pengembanga } \\
\text { n/ } \\
\text { Pembanguna } \\
\text { n Wilayah } \\
\text { Kerja }\end{array}$ & 5 & 5.997 .479 \\
\hline 7. & $\begin{array}{l}\text { Penasehat/ } \\
\text { Komisaris }\end{array}$ & 3 & 3.598 .487 \\
\hline \multicolumn{3}{|c|}{ SHU TAHUN 2016} & 119.949 .575 \\
\hline
\end{tabular}

Pendapatan yang diterima oleh Desa Wisata Candirejo bersumber dari beberapa paket wisata yang ditawarkan, yaitu:

\begin{tabular}{|c|c|c|}
\hline No & $\begin{array}{c}\text { Jenis Paket } \\
\text { Wiisata }\end{array}$ & Tarif Paket Wisata \\
\hline 1. & $\begin{array}{l}\text { Dokar Village } \\
\text { Tour. }\end{array}$ & Rp 150.000,-/ pax \\
\hline 2. & $\begin{array}{l}\text { Cycling Tour In } \\
\text { Candirejo } \\
\text { Village }\end{array}$ & Rp 150.000,-/ pax \\
\hline 3. & $\begin{array}{l}\text { Village } \\
\text { Experience }\end{array}$ & Rp 497.500,-/ pax \\
\hline 4. & Cooking Lesson & Rp 325.000,-/pax \\
\hline 5. & $\begin{array}{l}\text { Serenade at The } \\
\text { Foot of Menoreh } \\
\text { Hill }\end{array}$ & Rp 975.000,-/pax \\
\hline 6. & $\begin{array}{lr}\text { Stay at Local } \\
\text { House }\end{array}$ & Rp 497.500,-/ pax \\
\hline
\end{tabular}

\begin{tabular}{|c|c|c|}
\hline \multicolumn{3}{|c|}{ Candirejo } \\
\hline & Village (Home & \\
\hline & Stay) & \\
\hline 7. & Walking & Rp 100.000,-/ pax \\
\hline & Around Village & \\
\hline & + Refresment & \\
\hline 8. & Rafting & Rp 150.000,-/ pax \\
\hline 9. & Traditional & $\operatorname{Rp} \quad 2.500 .000,-/$ \\
\hline & Dance & Traditional Dance \\
\hline
\end{tabular}

Dampak positif Desa Wisata terhadap kondisi ekonomi tidak hanya dirasakan oleh masyarakat yang menjadi pelaku wisata, namun untuk yang tidak mejadi pelakupun mendapatkan pendapatan dari donasi dusun yang diberikan koperasi melalui kepala dusun dan kemudian dibagikan kepada warga dusun. Pada tahun 2016 jumlah donasi dusun yang diberikan sejumlah Rp 118.545.000,00 dengan perhitungan dusun memperoleh $\mathrm{Rp}$ 700,- / pax jika digunakan untuk kegiatan wisata dan Rp 300,- / pax untuk yang dilewati dokar.

Dampak desawisata terhadap perekonomian masyarakat dapat terlihat jelas dari adanya perbaikan kondisi perumahan dan pengembangan usaha baru yang dilaksanakan masyarakat desa wisata Candirejo, seperti dibukanya usaha kerajinan Bambu Ukir, Tikar Pandan, Batik Candirejo, Home Industri Sondok dan sebagainya. Produk dari usaha tersebut selain dijual pasar tradisional juga diperjual belikan kepada para wisatawan yang dating. Kegiatan tersebut secara tidak langsung memberikan kontribusi pendapatan masyarakat desa.

\section{Dampak Sosial}

Dampak sosial dapat terlihat dari meningkatnya interaksi sosial dan partisipasi masyarakat, serta adanya perubahan pola 
pikir masyarakat yang mulai sadar pentingnya pendidikan dan penguasaan bahasa asing. Hal ini dapat dilihat dari tabel berikut:

\begin{tabular}{lll}
\multicolumn{3}{c}{ Tabel Jumlah Penduduk Berdasarkan } \\
\multicolumn{3}{c}{ Struktur Pendidikan } \\
\hline No. & \multicolumn{1}{c}{$\begin{array}{c}\text { Tingkat } \\
\text { Pendidikan }\end{array}$} & $\begin{array}{c}\text { Jumlah } \\
\text { (orang) }\end{array}$ \\
\hline 1. & Tidak/Belum & 720 \\
& Sekolah & \\
2. & Lulus SD & 1.503 \\
3. & Lulus SMP & 1.024 \\
4. & Lulus SMA & 782 \\
5. & Akademi/ & 273 \\
\multicolumn{3}{l}{ Perguruan Tinggi } \\
\hline
\end{tabular}

Sumber: Pemetaan Swadaya Desa Candirejo,

$$
2010
$$

Dari tabel di atas dapat diketahui bahwa sebagian besar warga masyarakat Desa Wisata Candirejo sudah berpendidikan. Meskipun jumlah penduduk yang tingkat pendidikannya mencapai Perguruan Tinggi hanya sekitar 273 orang, lulusan SMA 782 orang, lulus SMP terdapat 1.024 orang, dan SD berjumlah 1.503 orang, namun semuanya jika ditotal lebih dari 50\% jumlah keseluruhan dan merupakan modal besar bagi pembangunan Desa Candirejo untuk terus berkembang.

Selain itu juga terdapat beberapa program pemberdayaan masyarakat yang dilakukan pihak koperasi untuk menunjang kemajuan Desa Wisata Candirejo antara lain adalah adanya pelatihan bahasa inggris, pelatihan cara menyambut tamu dengan baik, pelatihan tata ruang perumahan untuk penduduk yang menyediakan homestay, pelatihan pembuatan makanan atau kerajinan yang dilakukan dengan home industry, dan pemberian pengetahuan cara berinteraksi dengan tamu secara baik dan sopan. Pelatihan tersebut dilakukan secara periodik, terutama pada pelatihan bahasa inggris dan pelatihan tata ruang perumahan yaitu setiap tiga bulan sekali oleh tenaga yang berpengalaman di bidangnya.

\section{Dampak Budaya}

Dampak budaya yang nampak yaitu dengan adanya keanekaragaman kebudayaan Desa Wisata Candirejo yang disuguhkan kepada para wisatawan untuk menarik perhatian. Kebudayaan ini berupa kesenian tradisional yang berfungsi untuk melestarikan dan mengenalkan kebudayaan asli Indonesia kepada wisatawan asing pada khususnya. Kesenian yang dibawakan anak-anak Desa Wisata Candirejo ini sudah terkenal hingga beberapa kota seperti Yogyakarta dan Semarang karena pergelarannya yang menawan, sehingga tidak jarang mereka mendapat panggilan pergelaran di kota tersebut. Berikut ini daftar kesenian yang ada di Desa Wisata Candirejo:

\section{Tabel Kebudayaan Desa Wisata Candirejo}

\begin{tabular}{ll}
\hline No. & \multicolumn{1}{c}{ Nama Kesenian } \\
\hline 1. & Jatilan/ Kuda Lumping \\
2. & Wulangsunu/ Gatholoco \\
3. & Kubrosiswo \\
4. & Dayakan \\
5. Coke'an \\
6. Karawitan \\
7. & Sholawatn Jawa/ Pitutur \\
\hline \multicolumn{2}{c}{ Sumber: Profil Desa Wisata Candirejo, } \\
2016.
\end{tabular}

Asimilasi budaya secara kasat mata mulai nampak dan membawa pengaruh besar terhadap perubahan gaya hidup (life style) masyarakat salah satunyaBudaya gaya hidup bersih seperti membuang sampat pada tempatnya. Diakui oleh warga masyarakat budaya hidup bersih yang dibawa wisatawan asing memberikan peningkatan jumlah 
pengunjung yang dating hingga menginap di desa wisata Candirejo.

\section{Dampak Lingkungan}

Dampak lingkungan yang dapat dilihat secara nyata adalah pembangunan infrastruktur yang terselenggara tanpa menanti pendanaan dari Pemerintah. Perubahan yang terjadi yaitu adanya peningkatan kualitas dan pengembangan fasilitas publik dengan bantuan dana dari Koperasi Desa Wisata Candirejo. Fasilitas tersebut antara lain berupa tersedianya jaringan irigasi, listrik, telekomunikasi, dan pelayanan air bersih yang sudah merata ke seluruh penduduk, Prasarana jalan serta jembatan yang ada di desa juga dalam kondisi yang baik. Berikut ini kondisi jalan di Desa Wisata Candirejo:

\begin{tabular}{ccc}
\hline No. & $\begin{array}{c}\text { Kondisi } \\
\text { Jalan }\end{array}$ & $\begin{array}{c}\text { Luas Jalan } \\
\text { (km) }\end{array}$ \\
\hline 1. & Aspal & 1.041 \\
2. & Corblock & 3.9986 \\
3. & Paving Block & 2.8906 \\
4. & Macadam & 2.213 \\
5. & Tanah & 4.9859 \\
\hline
\end{tabular}

Sumber: diolah Peneliti, 2018.

Selanjutnya adanya pengelolaan dan pengembangan potensi Sumber Daya Alam sebagai objek wisata, seperti pemanfaatan lahan pertanian untuk sarana bercocok tanam wisatawan, dan pemanfaatan Sungai Tempuran dan Watu Kendil sebagai objek wisata yang menarik. Dana untuk pengembangan dan pembangunan wilayah tersebut sudah dialokasikan secara husus dari Koperasi Desa Wisata Candirejo yaitu sejumlah 3.598.487 rupiah untuk perbaikan dan kemajuan Desa Wisata Candirejo.

Perubahan Kondisi Desa Wisata Candirejo Pasca Menerapkan Community Based Tourism (CBT).
Perubahan kondisi desa Candirejo mulai mengarah pada perwujudan kemandirian, kondisi tersebut dapat diukur dari beberapa indikator pencapaian, diantaranya:

\section{Kebutuhan Dasar}

Pemenuhan kebutuhan dasar di Desa Wisata Candirejo sudah cukup terpenuhi melalui pendapatan yang di terima dari hasil pertanian atau pekerjaan pokok masyarakat serta pendapatan dari bagi hasil usaha desa wisata, misalnya pada tahun 2016 anggota koperasi yang merupakan warga masyarakat lokal menerima SHU sebesar Rp 41.982.351,00 atau $35 \%$ dari total pendapatan desa wisata.

2. Kegiatan Kemasyarakatan

Desa mandiri dapat tercermin dari intensifnya kegiatan kemasyarakatan terutama yang bersifat pemberdayaan yang pelaksanaan, fasilitas maupun dananya tidak tergantung pada pemerintah. Kegiatan kemasyarakatan di Desa wisata Candirejo yang bersifat pemberdayaan sudah cukup intensif dilaksanakan seperti program pelatihan bahasa inggris. Kegiatan tersebut dilaksanakan secara mandiri oleh masyarakat melalui pihak koperasi Desa Wisata Candirejo. Hasil dari kegiatan pelatihan Bahasa telah memberikan kontribusi pengurangan jumlah pengangguran di desa Candirejo. Hal ini di buktikan bahwa terdapat 9 pemandu wisata yang merupakan warga asli Candirejo yang bekerja menjadi pemandu yang menguasai Bahasa asing.

\section{Fasilitas Publik}

Fasilitas publik yang terselenggara guna memberikan kenyamanan pada warga desa sejak lahirnya desa wisata telah cukup layak dan terus mengalami peningkatan baik dari segi kualitas maupun kuantitas. 
Wujudnya berupa pembangunan panggung terbuka untuk kepentingan pagelaran seni masyarakat ataupun menyelenggarakan acara masyarakat, pembangunan paving jalan, revitalisasi objek-objek wisata desa, dan lainlain.

\section{Kegiatan Ekonomi}

Kegiatan ekonomi masyarakat Desa Wisata Candirejo setelah adanya desa wisata mengalami perubahan yang cukup berarti. Ekonomi masyarakat desa selain dari pertanian juga ditopang dari kegiatan usaha lainnya seperti dibukanya banyak home industry, warung makan, dan warung kelontong dan lain sebagianya.

Terpenuhinya beberapa indikator kemandirian desa diatas yang sebagian besar didukung oleh penerapan konsep Community Based Tourism di Desa Wisata Candirejo mengindikasikan bahwa Desa Wisata Candirejo berada pada kategori desa mandiri. Konteks mandiri disini tidak berarti bahwa desa terlepas dari dana bantuan pemerintah, namun setidaknya dalam pemenuhan kebutuhan dasar, kegiatan kemasyarakatan, pembangunan fasilitas publik, dan kegiatan perekonomian dapat berlangsung dengan mandiri. Peningkatan pendapatan (income generating) juga dirasakan oleh sebagian besar masyarakat desa Candirejo pada umumnya. Jumlah pendapatan yang dapat diserahkan kepada Pemerintah Desa pada tahun 2016 sebesar Rp 14.393.949,00.

\section{KESIMPULAN}

Dampak ekonomi Penerapan konsep CBT di Desa Wisata Candirejo memberikan adanya diversifikasi pekerjaan yang meningkatan penghasilan masyarakat., adanya perbaikan kondisi perumahan dan pengembangan usaha baru yang dilaksanakan masyarakat desa wisata Candirejo.

Dampak sosial dapat terlihat dari meningkatnya interaksi sosial dan partisipasi masyarakat, serta adanya perubahan pola pikir masyarakat akan pentingnya pendidikan serta pemberdayaan masyarakat.

Dampak budaya barat dari warga asing ibaarat keeping mata uang namun memiliki sisi yang sama sehingga memberikan dampak positif berupa gaya hidup bersih. Selain itu kesenian tradisional Indonesia tetap terjaga kelestariaannya.

Dampak lingkungan yang dapat dirasakan adalah peningkatan kualitas dan pengembangan fasilitas publik dengan bantuan dana dari Koperasi Desa Wisata Candirejo berupa donasi untuk desa.

Terpenuhinya Indikator Kemandirian desa Desa, bukan berarti penyelenggaraan pembangunan yang ada di Desa Candirejo tanpa sentuhan tangan Pemerintah. Namun, d alam pemenuhan kebutuhan dasar masyarakat terjadi peningkatan pendapatan (income generating), kegiatan kemasyarakatan, pembangunan fasilitas publik, dan kegiatan perekonomian yang ada bisa dipenuhi secara mandiri.

\section{DAFTAR PUSTAKA}

Adiyoso, W. 2009. Menggugat Perencanaan Partisipatif dalam Pemberdayaan Masyarakat. Jakarta: ITS Press.

Dewi Made HU, Fandeli Chafid, Baiquni M. 2013. Pengembangan Desa Wisata Berbasis Partisipasi Masyarakat Lokal Di Desa Wisata Jatiluwih Tabanan, Bali. [Jurnal KAWISTARA: Vol 3 N0 2]. [Internet]. [dikutip tanggal 28 September 2016]. Yogyakarta [ID]: 
UGM. Dapat diunduh dari: http://jurnal.ugm.ac.id/kawistara/ar ticle/download/3976/3251

Nasikun. 1997. Model Pariwisata Pedesaan: Pemodelan Pariwisata Pedesaan untuk Pembangunan Pedesaan yang Berkelanjutan. dalam Prosiding Pelatihan dan Lokakarya Perencanaan Pariwisata Berkelanjutan. Bandung: Institut Teknologi Bandung.

Nuryanti, W. 1999. Heritage, Tourism and

Local Communities. Yogyakarta: UGM Press.

Permendagri No 38/2010 tentang BUMDes

Purmada, Dimas Kurnia, dkk. 2016. "Pengelolaan Desa Wisata dalam Perspektif Community Based Tourism (Studi Kasus pada Desa Wisata Gubugklakah, Kecamatan poncokusumo, Kabupaten Malang)" dalam Jurnal Administrasi Bisnis Universitas Brawijaya, Maret 2016. Vol. 32, No.2

Sidik, Fajar. 2015. "Menggali Potensi Lokal Mewujudkan Kemandirian Desa" dalam Jurnal Kebijakan dan Administrasi Publik Sekolah Tinggi Pembangunan Masyarakat Desa "APMD", Yogyakarta, November 2015. Vol.19, No.2.

Suansri, Potjana. 2003. Community Based Tourism Handbook. Thailand : REST Project

Sumodiningrat, Gunawan. 2016. Membangun Indonesia dari Desa. Yogyakarta: Media Pressindo.

Sulistiyani, Ambar Teguh. 2004. Kemitraan dan Model-Model Pemberdayaan. Yogyakarta: Gava Media.
Sutopo, Ariesto Hadi dan Andrianus Arief. 2010. Terampil Mengolah Data Kualitatif dengan NVIVO. Jakarta: Prenada Media Group.

Timothy, D. J. 1999. Participatory Planning a View of Tourism in Indonesia dalam Annals of Research. [Jurnal: Vol 26 No 2]. [Internet]. [dikutip tanggal 28 September 2016]. Dapat diunduh dari: http://www.publishingindia.com/Ge tBrochure.aspx?query=UERGQnJvY2 h1cmVzfC80MjYucGRmfC80MjYucG $\mathrm{Rm}$.

Timothy, D.J., “Participatory Planning a View of Tourism in Indonesia" dalam Annuals Review of Tourism Research, XXVI (2) 1999.

Undang - Undang Nomor 6 Tahun 2014 tentang Desa

World Tourism Organization. 2000. WTO News Issue 2. Madrid. 